\section{Jarosław Ćwikła}

Prymasowski Instytut Kultury Chrześcijańskiej w Bydgoszczy

drjaroslaw.cwikla@gmail.com

DOI: http://dx.doi.org/10.12775/BPTh.2017.001

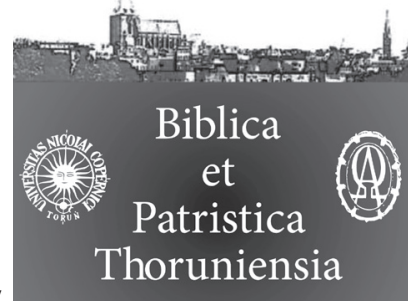

10 (2017) 1: 11-33

ISSN (print) 1689-5150

ISSN (online) 2450-7059

\title{
Umiejętność rozeznawania wartości doczesnych w perspektywie królestwa Bożego (Łk 14,15-24)
}

\section{Ability to of discernment the values worldly in the perspective of the Kingdom of God (LK 14:15-24)}

Streszczenie. W Ewangelii Łukasza zachodzi szereg krytycznych wypowiedzi na temat ludzi majętnych. Trzeci Ewangelista odnotował na przykład: „[Bóg] bogaczy odprawia z niczym” (Łk 1,53), „[...] biada wam bogaczom, bo odebraliście już waszą pociechę” (Łk 6,24), „Jak trudno tym, którzy mają dostatki, wejść do królestwa Bożego. Łatwiej jest wielbłądowi przejść przez ucho igielne, niż bogatemu wejść do królestwa Bożego" (Łk 18,24-25). Łukasz odnotował nie tylko pojedyncze zdania wymierzone w bogaczy, ale i obszerne fragmenty, na przykład: zapis kanoniczny o chciwości (Łk 12,13-21), tekst o bogatym dostojniku poszukującym drogi do zbawienia (Łk 18,18-30; par. Mk 10,17-31; Mt 19,16-30), przypowieść o bogaczu i Łazarzu (Łk 16,19-31), czy też perykopę o uczcie (Łk 14,15-24; par. Mt 22,1-14). Ostatni z wymienionych tekstów, a mianowicie fragment o uczcie (Łk 14,15-24), koncentruje się na umiejętności dokonywania wyborów w perspektywie królestwa Bożego. Jawi się on jako ostre upomnienie wymierzone w bogaczy. Jawi się jako ostrzeżenie, że karą dla nich za ich grzeszne wybory dokonywane $\mathrm{w}$ doczesności będzie potępienie wieczne.

Abstract. In Gospel of Luke there are a number of critical statements about rich people. The third Evangelist wrote down, for example: "[God] sent the rich away with empty hands" (Lk 1:53), "But how terrible for you who are rich now, you have had your easy life" (Lk 6:24), "How hard it is for rich people to enter the Kingdom of God. It is much harder for rich person to enter the Kingdom of God than for a camel to go through the eye of a needle" (Lk 18:24-25). The third Evangelist wrote down not only single, critical sentences about the rich, but extensive excerpts. He enrolled, for example: the text about the greed (Lk 12:13-21), the text of the rich man (Lk 18:18-30), the parable about the rich man and Lazarus (Lk 16:19-31), and the text of the great feast (Lk 14:15-24). The last one, namely the text about great feast (Lk 14:15-24) focuses on the ability to make choices in the perspective of the Kingdom of God. It is a sharp rebuke directed to the rich. Luke in this text warned the rich, that the penalty for them for their sinful choices in temporality, will be eternal damnation.

Słowa kluczowe: przypowieść; królestwo Boże; uczta; zaproszenie; bogacze; ubodzy; zbawienie; potępienie.

Keywords: a parable; the Kingdom of God; feast; invitation; the rich; the poor; salvation; damnation. 
\2ac się wypełnił i bliskie jest królestwo Boże. Nawracajcie się i wierzi o Jego sprawiedliwość, a [...] wszystko będzie wam dane" (Mt 6,33). Tymi słowami Jezus zachęcał przygodnie spotkanych ludzi do przemiany serca i pójścia drogą Ewangelii. Zachęcał ich, by szli nie przestronną, lecz wąską droga (Mt 7,13-14), by przechodzili nie przez szeroka, lecz przez cisną bramę (Mt 7,13-14; Łk 13,24). Namawiał ich również, aby spośród wielu wartości wybierali nie Mamonę, lecz Boga (Mt 6,24; Łk 16,13), nie wartości materialne, lecz duchowe, i wreszcie nie zło, lecz dobro. Z ubolewaniem jednak stwierdzał, że wielu ludzi odrzuca Jego rady ewangeliczne i kpi z orędzia zbawienia. A do grona Jego najzacieklejszych oponentów, wręcz wrogów, należeli ludzie majętni.

Ewangeliści w swoich zapisach kanonicznych nie próbowali ukrywać tego faktu. Mało tego, wielokrotnie podkreślali, że Jezusowi z trudem przychodziło ewangelizowanie bogatych. Szczególnie wiele krytycznych słów pod adresem bogaczy odnotował Łukasz, na przykład: „[Bóg] bogaczy odprawia z niczym” (Łk 1,53), „[...] biada wam bogaczom, bo odebraliście już waszą pociechę” (Łk 6,24), „Łatwiej jest wielbłądowi przejść przez ucho igielne, niż bogatemu wejść do królestwa Bożego" (Łk 18,25). Trzeci Ewangelista odnotował nie tylko pojedyncze zdania wymierzone w bogaczy, lecz także obszerne fragmenty, na przykład: zapis kanoniczny o chciwości (Łk 12,13-21), tekst o bogatym dostojniku poszukującym drogi do zbawienia (Łk 18,18-30; par. Mk 10,17-31; Mt 19,16-30), przypowieść o bogaczu i Łazarzu (Łk 16,19-31), czy też perykopę o uczcie (Łk 14,15-24; par. Mt 22,1-14).

Ostatnia $\mathrm{z}$ wymienionych perykop, a mianowicie perykopa o uczcie (Łk 14,15-24), koncentruje się na umiejętności dokonywania wyborów w perspektywie królestwa Bożego. Jawi się ona jako ostre upomnienie wymierzone w bogaczy. Jawi się jako ostrzeżenie, że karą dla nich za ich grzeszne wybory dokonywane w doczesności będzie potępienie wieczne. Wszelkie bowiem ludzkie, moralne wybory, dokonywane w doczesności, pociągają za sobą reperkusje na całą wieczność. Kto zatem w doczesności wybiera zamiast Boga dobra materialne, musi się liczyć z wykluczeniem z uczty niebiańskiej. Musi się liczyć z potępieniem wiecznym. Perykopa o uczcie (Łk 14,15-24) posiada zatem wydźwięk parenetyczny.

Z tego zaś względu, że kryje ona w sobie bogactwo treści, warto regularnie wczytywać się w nią i na nowo odkrywać jej przesłanie.

W niniejszym artykule zostanie więc przeanalizowana perykopa o uczcie (Łk 14,15-24). Dla przejrzystości artykuł zostanie podzielony na trzy części. W pierwszej części zostaną przedstawione zagadnienia literackie, w drugiej semantyczne, w trzeciej zaś - teologiczne. 
W pierwszej części zostaną zatem wytyczone granice zapisu kanonicznego Łk 14,15-24 i syntetycznie zaprezentowany jego kontekst oraz struktura. Z kolei w drugiej części zostaną objaśnione najbardziej kluczowe zwroty i terminy, które na późniejszym etapie badań, umożliwią pełniejsze odczytanie analizowanej perykopy. I wreszcie w trzeciej części zostanie przedstawiona nauka, wypływająca z omawianego tekstu Łk 14,15-24.

\section{Zagadnienia literackie zapisu kanonicznego Łk 14,15-24}

Przypowieść o uczcie występuje w dwóch Ewangeliach kanonicznych, w Ewangelii Łukasza i Mateusza. Odnotowana została również w apokryficznej Ewangelii Tomasza.

Co zatem należy sądzić o jej pochodzeniu? Otóż przyjmuje się, że pierwotnie należała ona do źródła $\mathrm{Q}^{1}$. Z tego zaś źródła zaczerpnęli ją wspomniani Ewangeliści. Oczywiście nie uczynili tego mechanicznie. Materiał bowiem, który zastali (Łk 14,16b-24), najpierw przepracowali i ubrali w nową szatę literacką, a następnie zredagowali. W efekcie ostateczna postać ich teksów ma wszystkie cechy charakterystyczne dla ich języka i stylu.

Już pobieżna lektura trzech wersji przypowieści o uczcie pozwala stwierdzić, że różnią się one między sobą.

Tekst Łukasza jest najkrótszy (Łk 14,16b-24). Koniecznie należy podkreślić, że trzeci Ewangelista opatrzył go własnym wstępem (Łk 14,15-16a) i w efekcie stworzył dwuczęściową perykopę o uczcie (Łk 14,15-24).

Natomiast fragment $\mathrm{z}$ apokryficznej Ewangelii Tomasza ${ }^{2}$ jest podobny do zapisu Łukasza, aczkolwiek nie identyczny i nieco dłuższy od niego. Wspomina

1 Zob. G. Schiwy, Weg ins Neue Testament. Kommentar und material, s. 349; A. Jankowski, Królestwo Boże w przypowieściach, s. 120; W. Grundmann, Das Evangelium nach Lukas, s. 296. Por. F. Gryglewicz, Ewangelia według św. Łukasza, s. 255.

2 Apokryficzna wersja przypowieści o uczcie jest podobna do wersji Łukasza. Oto jej treść: „Rzekł Jezus: Pewien człowiek miał [zaprosić] gości i gdy przygotował wieczerzę, posłał swego sługę, aby sprosił gości. Ten poszedł do pierwszego i powiedział mu: Pan mój zaprasza ciebie. Odrzekł: Mam pieniądze u kupców, oni przyjdą do mnie wieczorem; pójdę, aby wydać im polecenia. Wymawiam się od uczty. Poszedł do drugiego i powiedział mu: Pan mój zaprasza ciebie. Odrzekł mu: Kupiłem dom i proszą mnie na jeden dzień. Nie będę miał czasu. Poszedł do innego i powiedział mu: Pan mój zaprasza ciebie. Odrzekł mu: Mój przyjaciel będzie się żenił, a ja będę wydawał ucztę. Nie będę mógł przyjść. Usprawiedliwiam się od wieczerzy. Poszedł do innego i powiedział mu: Pan mój zaprasza ciebie. Odpowiedział mu: Kupiłem wieś, jestem w drodze, aby odebrać czynsz; nie będę mógł przyjść. Wymawiam się. Sługa przyszedł i powiedział swemu panu: Ci, których zaprosiłeś 
się w nim o próbie zaproszenia na ucztę nie trzech, lecz czterech gości. Ponadto posiada on inną szatę literacką.

Z kolei paralelny zapis występujący w Ewangelii Mateusza jest najdłuższy i różni się zarówno od wersji Łukasza, jak i Tomasza. Ale to nie dziwi. Składa się bowiem $\mathrm{z}$ dwóch pierwotnie niezależnych od siebie przypowieści, a mianowicie z paraboli o uczcie (Mt 22,2-10) pochodzącej ze źródła Q i z Mateuszowej paraboli o szacie godowej (Mt 22,11-14). Przyjmuje się, że Mateusz dopiero na etapie redakcji połączył obie te parabole i opatrzył je wstępem (Mt 22,1). $\mathrm{W}$ efekcie opracował rozbudowaną perykopę o godach syna królewskiego (Mt $22,1-14)^{3}$.

Zatem trzy wersje przypowieści o uczcie występujące w Ewangelii Łukasza, Mateusza i Tomasza różnią się od siebie. Różnią się zarówno szatą literacką, jak i wymową teologiczną. $Z$ tego zaś względu, że wersja Łukasza jest najkrótsza, należy przyjąć, że jest ona najbliższa oryginałowi, pochodzącemu ze źródła Q.

\subsection{Granice zapisu kanonicznego Łk 14,15-24 i jego kontekst}

\subsubsection{Granice perykopy o uczcie ( $t k 14,15-24)$}

W Ewangelii Łukasza perykopa o uczcie (Łk 14,15-24) znajduje się po zachęcie Jezusa skierowanej do uczniów, by byli skromni (Łk 14,7-11) i by zapraszali na przyjęcie nie bogatych, lecz ubogich (Łk 14,12-14), a przed Jego nauką o powinnościach chrześcijanina (Łk 14,25-35). Już pobieżna lektura 14 rozdziału Ewangelii Łukasza pozwala stwierdzić, że analizowany fragment idealnie wpisuje się w swój kontekst. Jednak dopiero wnikliwa analiza, pozwali dokładnie ustalić jego granice.

Żeby bowiem ustalić granice omawianego tekstu Łk 14,15-24, nie do końca można zastosować klasyczne kryteria: miejsca, czasu i osób. Wszystkie bowiem wydarzenia opisane przez Łukasza począwszy od wersetu Łk 14,1 aż do Łk 14,24, a więc i w analizowanym fragmencie, dzieją się w tym samym miejscu (dom faryzeusza), w tym samym czasie (szabat) i w obecności tych samych osób (goście

na ucztę, wymówili się. Rzekł pan do swego sługi: Wyjdź na drogi i tych, których znajdziesz, przyprowadź, aby wieczerzali; kupcy i handlarze nie wejdą do miejsca mego Ojca" (Ew Tm 64). (Zob. Ewangelie Apokryficzne, w: Apokryfy Nowego Testamentu, red. M. Starowieyski, s. 130).

3 Zob. Ch. H. Dodd, Przypowieści o Królestwie, s. 92; K. Romaniuk, Morfokrytyka i historia redakcji czyli Form - i Redaktionsgeschichte, s. 108; K. Romaniuk, Przyjacielu, jakżeś tu wszedt nie majac szaty godowej (Mt 22,1-14), s. 271; R. Rubinkiewicz, Przypowieść o szacie godowej (Mt 22,11-13) w świetle Hen 10,4, s. 63; L. Mattern, Przypowieść o uczcie, kol. 1095; M. Wojciechowski, Przypowieści dla nas, s. 97; K. Romaniuk, A. Jankowski, L. Stachowiak, Komentarz praktyczny do Nowego Testamentu, s. 130; G. Ricciotti, Życie Jezusa, s. 470. 
zebrani na uczcie u faryzeusza). Żeby zatem ustalić granicę górną analizowanego fragmentu, kryteria te na niewiele się przydadzą. Oczywiście można je zastosować, aby ustalić granicę dolną omawianej perykopy Łk 14,15-24, gdyż następująca po omawianym tekście, perykopa o powinnościach chrześcijanina (Łk 14,25-35), przenosi akcję poza dom faryzeusza (zmiana miejsca), opisuje wydarzenia, które nie dzieją się już w szabat (zmiana czasu) i wreszcie wspomina o pojawieniu się wokół Jezusa nowych tłumów, o których jeszcze w 14 rozdziale nie wzmiankowano. Jednak to za mało, aby całkowicie obramować analizowany tekst.

Jak zatem można ustalić granice perykopy o uczcie? Otóż żeby to uczynić, należy odwołać się do stylu Łukasza. Jak wiadomo jedną z cech stylu Łukasza jest dopisywanie własnych wstępów do perykop, które przejmował z innych źródeł. A jak już wcześniej zasygnalizowano, omawiana perykopa Łk 14,15-24 składa się właśnie ze wstępu Łukaszowego autorstwa ( Łk 14,15-16a) i z przypowieści o uczcie (Łk 14,16b-24), zaczerpniętej przez niego ze źródła Q. Odznacza się więc wspomnianą, charakterystyczną cechą jego stylu.

Zatem już na tym etapie badań można stwierdzić, że klamrą obejmującą analizowany tekst są wersety Łk 14,15 i Łk 14,24. Ale to nie koniec argumentów, gdyż koronnym argumentem potwierdzającym słuszność obramowania tekstu w granicach tak ustalonych, jest argument wynikający z treści analizowanej perykopy.

Analizowaną perykopę rozpoczyna sentencja: „Słysząc to, jeden ze współbiesiadników rzekł do Niego: Szczęśliwy ten, kto będzie ucztował w królestwie Bożym" (Łk 14,15).

Werset 15, werset otwierający omawiany fragment, co prawda kontynuuje motyw uczty wprowadzony przez trzeciego Ewangelistę już w wersecie Łk 14,1, to jednak na sposób transpozycji wprowadza nową jego odsłonę. O ile bowiem do wersetu Łk 14,14 trzeci Ewangelista opisywał ucztę rozumianą wyłącznie w kategoriach doczesnych, o tyle od wersetu $Ł k$ 14,15, z regularną konsekwencją, aż do wersetu Łk 14,24, zaczął przedstawiać ucztę rozumianą w kategoriach duchowych, zaczął przedstawiać ucztę w królestwie Bożym. I to jest novum wyróżniające omawiany zapis kanoniczny Łk 14,15-24 z jego kontekstu.

Werset 24, a więc werset kończący omawiany tekst, zawiera słowa: „Albowiem powiadam wam: Żaden z owych ludzi, którzy byli zaproszeni, nie skosztuje mojej uczty" (Łk 14,24). Słowa te są .przestrogą skierowaną głównie do bogaczy, ale nie tylko. Są bowiem skierowane do tych wszystkich, którzy z grona wielu wartości zamiast Boga wybierają dobra materialne, zamiast wartości wiecznych wybierają wartości doczesne. Oni za karę zostaną wykluczeni z udziału w uczcie niebiańskiej.

$\mathrm{Z}$ tego więc względu, że zarówno wstęp (Łk 14,15-16a), jak i cała - od pierwszego aż do ostatniego wersetu - harmonijnie połączona $\mathrm{z}$ nim przypowieść (Łk 14,16b-24), dotyczą ucztowania w królestwie Bożym, słusznym jest mówienie o analizowanym fragmencie w granicach już wcześniej wskazanych. Tylko bo- 
wiem tak obramowany tekst będzie idealnie wpisywał się w swój kontekst i wyróżnił z niego. Tylko tak obramowany tekst będzie spójny pod względem logicznym. I wreszcie tylko tak obramowany tekst będzie spełniał wszystkie wymogi języka i stylu Łukasza. Klamrą zatem obejmującą Łukaszową perykopę o uczcie są wersety Łk 14,15 i Łk 14,24 .

\subsubsection{Kontekst fragmentu o uczcie ( Łk 14,15-24)}

Łukasz poprzedził perykopę o uczcie (Łk 14,15-24) trzema tekstami, a mianowicie: perykopą o nowych uzdrowieniach w szabat (Łk 14,1-6), zapisem kanonicznym o skromności (Łk 14,7-11) i fragmentem o zapraszaniu na ucztę (Łk 14,12-14). Z kolei w kontekście następującym po perykopie o uczcie (Łk 14,15-24) umieścił tekst, który jest streszczeniem kluczowych obowiązków chrześcijanina (Łk 14,25-35) .

Już pobieżna lektura tych tekstów pozwala stwierdzić, że wszystkie te fragmenty cechuje stała dążność do ukazania, jakim winien być prawdziwy uczeń Jezusa $\mathrm{w}$ relacji do bliźniego, szczególnie najuboższego. Wynika zaś z nich, że uczeń Jezusa winien być wielkoduszny i hojny, że powinien odznaczać się skromnością i miłosierdziem, roztropnością i rozsądkiem. Wynika z nich również, że powinien wyrzec się wszystkiego, co posiada, że powinien stać się ubogim tak w wymiarze materialnym, jak i duchowym. Tylko bowiem wtedy będzie mógł całym sercem przylgnąć do Jezusa i zostać Jego uczniem. Tylko wtedy zasłuży na udział w uczcie niebiańskiej ${ }^{5}$.

4 Zob. F. Gryglewicz, Ewangelia według św. Łukasza, s. 254-260; T. Loska, Ewangelie z komentarzem duszpasterskim, s. 704-707; M. Wolniewicz, Ewangelia według Łukasza, s. 190-192.

5 Mateusz umieścił perykopę o godach syna królewskiego (Mt 22,1-14) w zupełnie innym kontekście niż Łukasz. W kontekście poprzedzającym zanotował bowiem sześć perykop, a mianowicie: perykopę o uroczystym wjeździe Jezusa do Jerozolimy (Mt 21,1-11), zapis kanoniczny o gniewie Jezusa w świątyni (Mt 21,12-17) i fragment o nieurodzajnym drzewie figowym (Mt 21,18-22). Zaprezentował również tekst dotyczący władzy Jezusa (Mt 21,23-27) oraz dwie przypowieści: parabolę o dwóch synach (Mt 21,28-32) i parabolę o przewrotnych rolnikach (Mt 21,33-46). Z kolei w kontekście następującym po perykopie o godach syna królewskiego (Mt 22,1-14), odnotował cztery teksty: perykopę o płaceniu podatku świątynnego (Mt 22,15-22), fragment o zmartwychwstaniu (Mt 22,23-33) oraz zapisy o największym przykazaniu (Mt 22,34-40) i o Mesjaszu, Synu Bożym (Mt 22,41-46). Co łączy te teksty? Otóż pod względem chronologicznym, wszystkie te perykopy budują spójną i logiczną narrację. Cechuje je zaś stała dążność do wyeksponowania narastającego napięcia, jakie wytworzyło się między Jezusem a Żydami pod koniec Jego publicznej działalności.. A zatem Mateuszowa 


\subsection{Struktura zapisu o uczcie (Łk 14,15-24)}

Perykopy zachodzące w Ewangelii Łukasza bardzo często składają się z dwóch części. Tą cechą odznacza się już Prolog trzeciej Ewangelii (Łk 1,1-4). Można bowiem wyodrębnić $\mathrm{w}$ nim dwie części, a mianowicie wzmiankę o pracy Ewangelistów redagujących Dobrą Nowinę (pierwsza część: Łk 1,1-2) oraz informację o pracy Łukasza tworzącego podobne dzieło (druga część: Łk 1,3-4). Tą cechą odznacza się także perykopa o chciwości (Łk 12,13-21). I ona jest wyraźnie dwuczłonowa. Składa się bowiem z nauki Jezusa dotyczącej chciwości (pierwszy człon: Łk 12,13-15) oraz z Jego przypowieści o nierozważnym bogaczu (drugi człon: Łk 12,16-21), Tę cechę posiada również przypowieść o bogaczu i Łazarzu (Łk 16,19-31), gdyż i w jej strukturze wyraźnie można wyodrębnić dwa elementy, a mianowicie: opis życia doczesnego bogacza i żebraka imieniem Łazarz (pierwszy element: Łk 16,19-22) oraz opowiadanie o ich losach po śmierci (drugi element: Łk 16,23-31).

Jak już wcześniej sygnalizowano, także omawiana perykopa Łk 14,15-24 jest dwuczęściowa, gdyż w jej strukturze można wyróżnić: wstęp (pierwsza część: Łk 14,15-16a) oraz harmonijnie połączoną z nim przypowieść o uczcie (druga część: Łk 14,16b-24).

Wstepp (Łk 14,15-16a)

Łk 14,15-16a: „Słysząc to, jeden ze współbiesiadników rzekł do Niego: Szczęśliwy ten, kto będzie ucztował w królestwie Bożym. On zaś mu powiedział:".

\section{Przypowieść Jezusa ( $Ł k$ 14,16b-24)}

Łk 14,16b: $\quad$ zapis o bogaczu, który urządzał ucztę,

Łk 14,17: misja sługi zobowiązanego do zaproszenia gości,

Łk 14,18-20: wymówki trzech zaproszonych gości, którzy odmówili udziału w uczcie,

Łk 14,21: powrót sługi (21a) i gniew pana (21b); druga misja sługi (21c),

Łk 14,22: $\quad$ powrót sługi $\mathrm{z}$ drugiej misji,

Łk 14,23: trzecia misja sługi,

Łk 14,24: $\quad$ sentencja kończąca przypowieść: „Albowiem powiadam wam, żaden z owych ludzi, którzy byli zaproszeni, nie skosztuje mojej uczty".

perykopa, z całym swym kontekstem, posiada zupełnie inny wydźwięk teologiczny, niż paralelny tekst zachodzący w Ewangelii Łukasza. 
Z powyższego wykazu wynika, że perykopa o uczcie (Łk 14,15-24) tworzy jednolite, spójne dzieło. Ważną zaś rolę pełni w niej symbolika liczby trzy. Łukasz wspomina bowiem o trzech gościach, którzy odrzucili zaproszenie na ucztę (Łk 14,18-20), wspomina o trzech różnych powodach, dla których zaproszeni odmówili udziału w przyjęciu (Łk 14,18-20) i wreszcie wspomina o trzech ponawianych przez gospodarza próbach, by zgromadzić gości na ucztę (pierwsze zaproszenie: Łk 14,17; drugie zaproszenie: Łk 14,21c; trzecie zaproszenie: Łk 14,23). Zatem w omawianej perykopie symbolika liczby trzy jest wyraźnie obecna. Warto podkreślić, że swymi korzeniami sięga ona tradycji biblijnej, dotyczącej świadków i świadectwa.

Jak wiadomo, w czasach biblijnych za wiarygodne świadectwo uchodziło tylko takie, które było złożone przez przynajmniej dwóch, trzech świadków. Nic więc dziwnego, że Autorzy biblijni często w swoich tekstach odwoływali się do liczby trzy.

Na przykład Ewangeliści wspominają o trzech pokusach, jakimi Jezus był próbowany na pustyni (Mt 4,1-11; Łk 4,1-13). Wspominają również o trzech uczniach obecnych wraz z Jezusem na górze Tabor (Mt 17,1; Mk 9,2; Łk 9,28). Wzmiankują o tych samych trzech uczniach, obecnych z Jezusem w Ogrójcu (Mt 26,37; Mk 14,33). Przytaczają trzy zapowiedzi męki i śmierci Jezusa (pierwsza zapowiedź: Mt 16,21-23; Mk 8,31-33; Łk 9,22; druga zapowiedź: Mt 17,22-23; Mk 9,30-32; Łk 9,43b-45; trzecia zapowiedź: Mt 20,17-19; Mk 10,32-34; J 18,32). Odnotowali również proroctwo Jezusa o potrójnej zdradzie Piotra, o jego potrójnym wyparciu się znajomości z Jezusem (Mt 26,34; Mk 14,30; Łk 22,34; J 13,38). A Jan w swojej Ewangelii utrwalił trzy pytania o miłość, jakie zmartwychwstały Jezus skierował do Piotra (J 21,15-19).

Dzięki zaś symbolice liczby trzy, Ewangeliści w wyżej wymienionych zapisach wzmocnili świadectwo opisywanych przez siebie wydarzeń i w ten sposób uczynili je w najwyższym stopniu wiarygodnymi.

A co z Łukaszem i jego perykopą o uczcie? Otóż i on dzięki symbolice liczby trzy po pierwsze, wzmocnił parenetyczne przesłanie swojej perykopy. Wzmocnił ostrzeżenie skierowane do bogaczy, że karą za ich grzeszne wybory dokonywane w doczesności, będzie potępienie wieczne. Po drugie, złożył wiarygodne świadectwo, że to nie tyle Bóg wyklucza człowieka z udziału w uczcie niebiańskiej, ile sam człowiek wyklucza z niej siebie, że to nie tyle Bóg potępia człowieka, ile człowiek potępia siebie. I wreszcie po trzecie, złożył uwierzytelnione świadectwo, że Bóg z nie słabnącą cierpliwością, zapraszana na swoją ucztę, że zaprasza zarówno bogatych, jak i ubogich. 


\section{Pole semantyczne zapisu kanonicznego Łk 14,15-24}

„14 ${ }^{15}$ Słysząc to jeden ze współbiesiadników rzekł do Niego: Szczęśliwy ten, kto

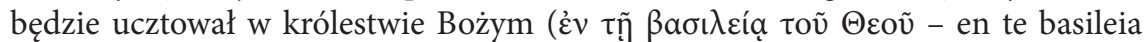
tou Theou). ${ }^{16}$ On zaś mu powiedział: Pewien człowiek wyprawiał wielką ucztę

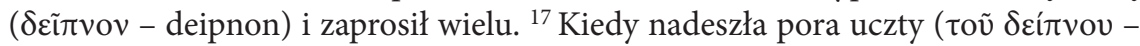

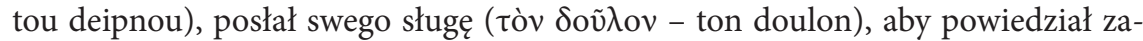
proszonym: Przyjdźcie, bo już wszystko jest gotowe. ${ }^{18}$ Wtedy zaczęli się wszyscy jednomyślnie (áđò $\mu$ ãc - apo mias) wymawiać. Pierwszy kazał mu powiedzieć:

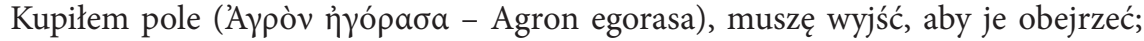
proszę cię, uważaj mnie za usprawiedliwionego. ${ }^{19}$ Drugi rzekł: Kupiłem pięć par

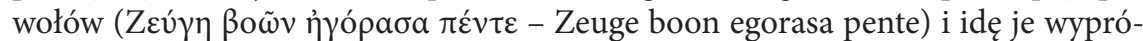
bować; proszę cię, uważaj mnie za usprawiedliwionego. ${ }^{20}$ Jeszcze inny rzekł: Poślubiłem żonę (Гuvaĩka દ̌ $ү \eta \mu \alpha$ - Gynaika egema) i dlatego nie mogę przyjść. ${ }^{21}$ Sługa

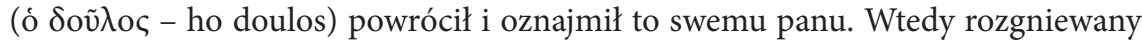

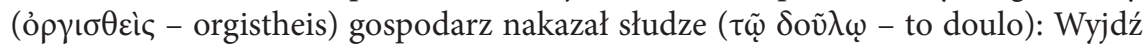

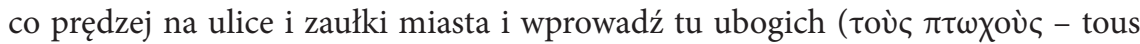

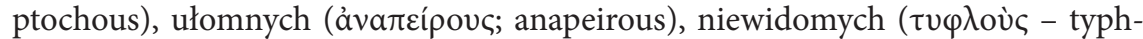

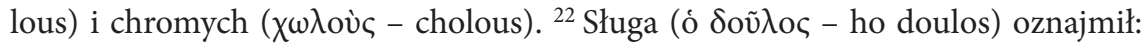

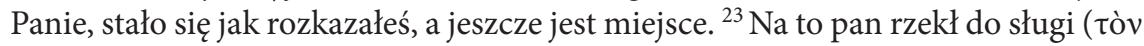

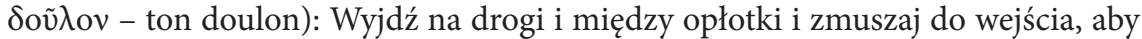
mój dom był zapełniony. ${ }^{24}$ Albowiem powiadam wam: Żaden z owych ludzi, któ-

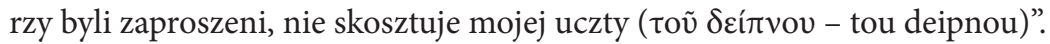

Jak już wcześniej wzmiankowano, Łukaszowa perykopa o uczcie składa się z dwóch części, gdzie pierwszą część stanowi wstęp (Łk 14,15-16a), drugą zaś

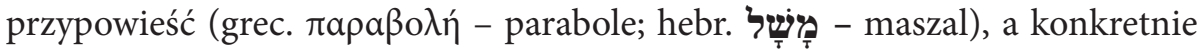
przypowieść o uczcie (Łk 14,16b-24).

Jezus opowiedział tę parabolę pod koniec swojej publicznej działalności. Wygłosił ją w szabat, w domu jednego z przywódców faryzeuszów. Wygłosił ją podczas posiłku (Łk 14,1).

Centralną postacią tej paraboli jest zamożny człowiek. Z relacji Łukasza wynika, że był on nad wyraz towarzyski, że lubił otaczać się przyjaciółmi i znajomymi, że lubił ucztować i świętować. Nic więc dziwnego, że któregoś dnia postanowił wyprawić ucztę ( $\delta \varepsilon i \tilde{\pi} v$ ov - deipnon; Łk 14,16).

Zachodzący w analizowanej perykopie grecki rzeczownik $\delta \varepsilon \tilde{\tau} \pi$ vov (deipnon), oznacza zwykły codzienny posiłek, obiad i wieczerzę. Oznacza również uroczyste przyjęcie i ucztę, a jego hebrajskim odpowiednikiem jest termin

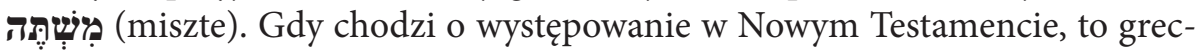


ki rzeczownik $\delta \varepsilon i ̃ \pi v o v(d e i p n o n)$ pojawia się w nim 16 razy $^{6}$, np.: „W czasie wieczerzy ( $\delta \varepsilon i ́ \pi v o v$ - deipnou), gdy diabeł już nakłonił serce Judasza Iskarioty, syna Szymona, aby Go wydał” (J 13,2). „[Uczeni w Piśmie i faryzeusze] lubią

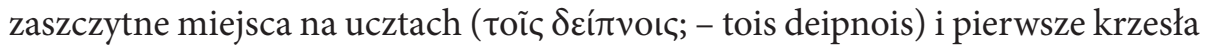
w synagogach” (Mt 23,6). „[...] błogosławieni, którzy są wezwani na ucztę (

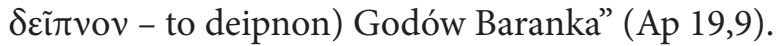

Z lektury przytoczonych zapisów wynika zatem, że termin $\delta \varepsilon \tilde{\pi}$ vov (deipnon) określa ucztę doczesną bądź wieczną. Określa przyjęcie w gronie domowników i przyjaciół, bądź zbawienie w królestwie Bożym.

Koniecznie należy podkreślić, że termin ten kryje w sobie bogatą symbolikę, która na trwałe wpisała się w tradycję biblijną. W czasach biblijnych wyobrażano sobie bowiem czasy mesjańskie, jako stan niekończącej się uczty, jako stan wiekuistego szczęścia. Wyobrażano więc sobie Boga, który wyprawi ucztę i zaprosi na nią wszystkie swoje dzieci. Między zaś Nim a zaproszonymi gośćmi oraz między zaproszonymi nawzajem, będzie panowała wzajemna miłość, życzliwość i sympatia (Oz 3,1-5; Iz 54,4-10; Ap 19,1-9). I nikt niegodny nie będzie mógł partycypować w ich radości. Mało tego, nikt niegodny nie będzie mógł zakłócić ich świętowania?

Rzeczownik $\delta \varepsilon i ̃ \pi v o v$ (deipnon) posiada zatem głębokie teologicznie znaczenie i należy do podstawowych pojęć biblijnych.

Bogacz wyprawiający ucztę, nie musiał zapraszać swoich gości osobiście. Zgodnie z obowiązującym zwyczajem, mógł z zaproszeniem posłać do nich

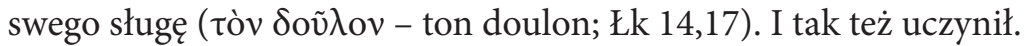

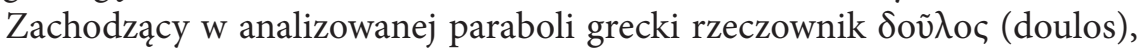
oznacza niewolnika, sługę i poddanego. Jego więc hebrajskimi odpowiednika-

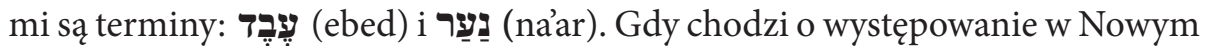

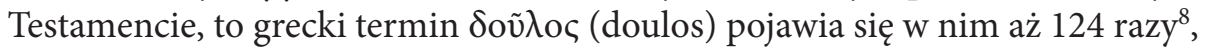
np.: „Bo i ja, choć podlegam władzy, mam pod sobą żołnierzy. Mówię temu:

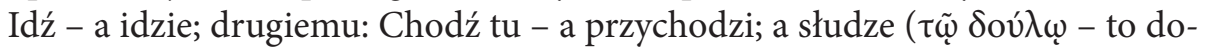
ulo): Zrób to - a robi”. (Mt 8,9). „Zaprawdę, zaprawdę powiadam wam: Każdy

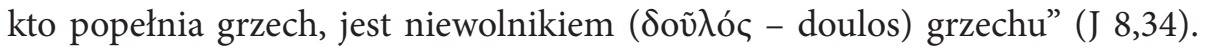

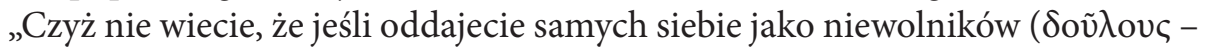

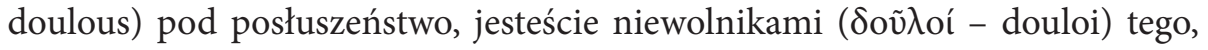

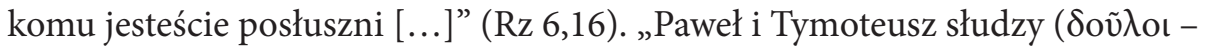

6 Zob. Z. Abramowiczówna, Słownik grecko-polski, t. I, s. 502; R. Popowski, Wielki słownik grecko-polski Nowego Testamentu, s. 120.

7 Zob. E. Szymanek, Wykład Pisma Świętego Nowego Testamentu, s. 122.

8 Zob. Z. Abramowiczówna, Słownik grecko-polski, t. I, s. 599; R. Popowski, Wielki słownik grecko-polski Nowego Testamentu, s. 144. 
douloi) Chrystusa Jezusa, do wszystkich świętych w Chrystusie Jezusie [...]" (Flp 1,1).

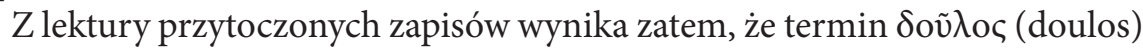
oznacza sługę i niewolnika w wymiarze duchowym bądź społecznym. Duchowym, bo możne oznaczać człowieka uległego i posłusznego Bogu. Można również oznaczać zniewolonego przez zło, grzech i szatana. Z kolei społecznym, bo w relacjach międzyludzkich może określać człowieka, podlegającego różnym formom podporządkowania, w tym zniewolenia9 .

Sługa, jeden $\mathrm{z}$ bohaterów omawianej przypowieści, wypełnił powierzoną mu przez pana misję. Dotarł bowiem do domów potencjalnych gości swego pana i przekazał im zaproszenia. Niestety, oni jednomyślnie (ả̇ò $\mu$ ã $\varsigma$ - apo mias) ich nie przyjęli (Łk 14,18).

W Starym Testamencie znany był co prawda zwyczaj, polegający na kurtuazyjnym nieprzyjęciu pierwszego zaproszenia, jednak w tym przypadku nie miał on zastosowania. Z Ewangelii Łukasza wynika bowiem, że potencjalni goście wcale nie zamierzali odwiedzić swego gospodarza. Nie przyjęliby zatem żadnego następnego zaproszenia. Dlaczego? Otóż tłumaczyli się nad wyraz pokrętnie i niegrzecznie, a nawet arogancko i butnie.

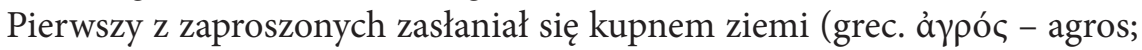
hebr. אֶרִ - erec). Twierdził, że właśnie planuje obejrzeć swoją nową posiadłość, stąd nie może przyjść na ucztę (Łk 14,18). Jest to wielce nieprawdopodobne. W czasach biblijnych każdy bowiem szanujący się nabywca ziemi, najpierw dokładnie ją oglądał i sprawdzał jej wartość, a dopiero potem, po długim targu $\mathrm{z}$ aktualnym właścicielem, kupował. Nie odwrotnie.

W podobnej tonacji tłumaczył się także drugi z zaproszonych. Twierdził, że kupił 10 wołów $^{10}$ (grec. 1. poj. ßoṽc - bous; hebr. l. poj. רשוֹ - szor) i właśnie zamierza sprawdzić ich wartość (Łk 14,19). I to tłumaczenie jest niewiarygodne. W starożytności biblijnej każdy bowiem szanujący się kupiec, gdy nabywał zwierzęta, najpierw je dokładnie oglądał, wręcz badał. Najpierw więc sprawdzał ich wiek, stan zdrowia i przydatność do gospodarstwa, a następnie po długim targu z aktualnym właścicielem, kupował. Każda inna procedura świadczyłaby o ignorancji kupca. I źle świadczyłaby o nim.

9 Zob. A. Ohler, G. Hierzenberger, Stuga, kol. 1211; X. Leon-Dufour, Słownik Nowego Testamentu, s. 572; J. K. Pytel, List do Filipian, s. 469.

10 Skoro drugi z zaproszonych na ucztę kupił 10 wołów, oznacza to, iż musiał posiadać od 100 do 200 ha ziemi. Tylko bowiem wtedy, z ekonomicznego punktu widzenia, taki zakup miał sens. A zatem bohater omawianej perykopy był człowiekiem bardzo bogatym. (Zob. A. Jankowski, Królestwo Boże w przypowieściach, s. 123). 
Z kolei trzeci z zaproszonych gości nie przyjął zaproszenia, ponieważ po-

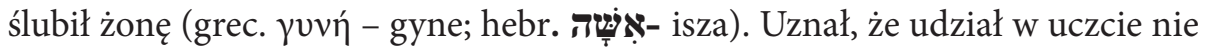
jest warty nawet chwilowej rozłąki z żoną (Łk 14,20).

Zatem potencjalni goście $\mathrm{w}$ butny sposób zlekceważyli zaproszenie na ucztę $^{11}$. O tym zaś fakcie sługa powiadomił swojego pana, czym bardzo go rozgniewał (Łk 14,21).

Zachodzący w analizowanej perykopie Łk 14,15-24 grecki czasownik

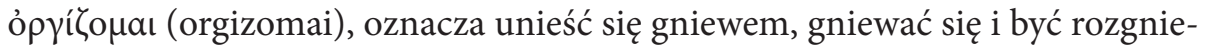
wanym. Oznacza również być oburzonym, a w Nowym Testamencie występuje

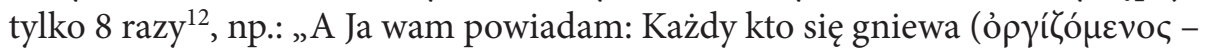
orgizomenos) na swego brata, podlega sądowi” (Mt 5,22). „Na to rozgniewał się ( $\omega \rho \gamma i ́ \sigma \theta \eta$ - orgisthe) i nie chciał wejść” (Łk 15,28). „I rozgniewał się ( $\omega p \gamma i ́ \sigma \theta \eta$ - orgisthe) Smok na Niewiastę i odszedł rozpocząć walkę z resztą jej potomstwa" (Ap 12,17).

Z przytoczonych zapisów wynika zatem, że Autorzy biblijni za pomocą cza-

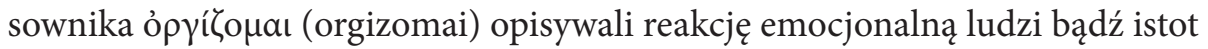
duchowych. Opisywali stan ich silnego pobudzenia, zdenerwowania i wzburzenia.

Przyjęcie urządzane przez bogacza nie było jego chwilowym kaprysem, ale dobrze przemyślaną decyzją. Skoro więc najznakomitsi goście nie przyjęli zaproszenia, nie zraził się tym. Wysłał bowiem swego sługę po nowych go-

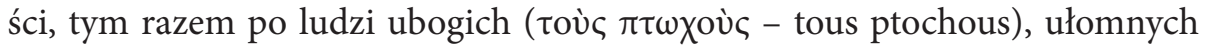

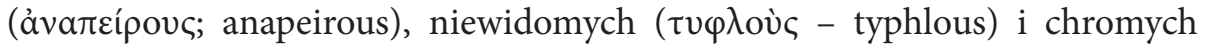
( $\chi \omega \lambda$ ov̀ $\varsigma$ - cholous) - Łk 14,21.

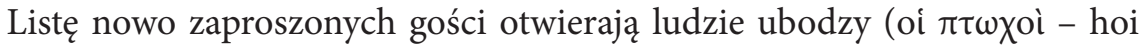
ptochoi). Zachodzący w omawianej perykopie przymiotnik $\pi \tau \omega \chi o ́ \varsigma$ (ptochos), oznacza człowieka lichego, marnego i mizernego. Oznacza również biednego, nędznego, ubogiego i żebrzącego ${ }^{13}$. Jego więc hebrajskimi odpowiednikami są

11 Tłumaczenia trzech gości rezygnujących z uczty, przypominają wyjaśnienia, jakie składali Izraelici, którzy chcieli uniknąć pójścia na wojnę. Od udziału w wojnie mogli bowiem wymówić się ci, którzy zbudowali dom, nabyli pole, bądź wstąpili w związek małżeński: „Kto z was zbudował nowy dom, a jeszcze go nie poświęcił, niech wraca do swego domu, bo mógłby zginąć na wojnie, i kto inny by go poświęcił. Kto z was zasadził winnicę, a nie zebrał jej owoców, niech wraca do domu, bo mógłby zginąć na wojnie, a kto inny by zebrał jego owoce. Kto żonę poślubił, a jeszcze jej nie sprowadził do siebie, niech wraca do domu, bo mógłby zginąć na wojnie, a kto inny by ją sprowadził do siebie" (Pwt 20,5-7).

12 Zob. R. Popowski, Wielki słownik grecko-polski Nowego Testamentu, s. 435.

13 Zob. Z. Abramowiczówna, Słownik grecko-polski, t. III, s. 762; R. Popowski, Wielki słownik grecko-polski Nowego Testamentu, s. 539-540. 


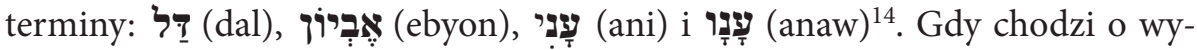
stępowanie w Nowym Testamencie, to grecki przymiotnik $\pi \tau \omega \chi$ ó $\varsigma$ (ptochos) pojawia się w nim 34 razy ${ }^{15} \mathrm{np} .:$,idź, sprzedaj, co posiadasz i rozdaj ubogim

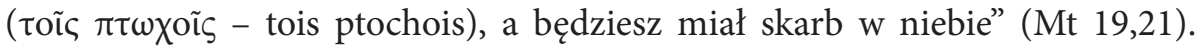
„Przecież można było drogo to sprzedać i rozdać ubogim” ( $\pi \tau \omega \chi \chi \tilde{\iota} \varsigma$ - ptochois; Mt 26,9). „Kiedy urządzasz przyjęcie, zaproś ubogich ( $\pi \tau \omega \chi o v ́ \varsigma$ - ptochous)

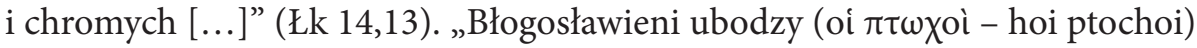
w duchu, albowiem do nich należy królestwo niebieskie" (Mt 5,3).

Z lektury przytoczonych tekstów wynika zatem, że termin $\pi \tau \omega \chi 0$ ৎ (ptochos), oznacza ubogiego bądź w wymiarze materialnym, bądź duchowym.

Jak już wspomniano, gospodarz uczty swoje zaproszenie wystosował rów-

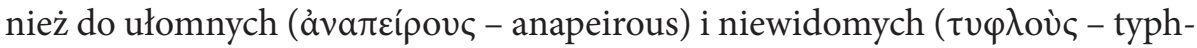
lous) - Łk 14,21.

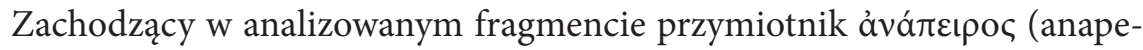
iros), oznacza człowieka okaleczałego i ułomnego ${ }^{16}$, a w Nowym Testamencie pojawia się tylko 2 razy i zawsze w Ewangelii Łukasza (Łk 14,13.21).

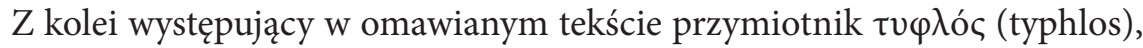
określa ślepego, niewidomego, ociemniałego, a w księgach Nowego Przymierza zachodzi 50 razy ${ }^{17}$, np.: „Zostawcie ich. To są ślepi ( $\tau \cup \varphi \lambda$ oí - typhloi) przewod-

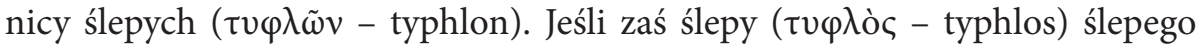
( $\tau \varphi \varphi \lambda$ òv - typhlon) prowadzi, obaj w dół wpadną" (Mt 15,14). „Jezus przechodząc obok ujrzał pewnego człowieka niewidomego ( $\tau \varphi \varphi \lambda$ òv - typhlon) od urodzenia” (J 9,1). „Komu bowiem ich [cnót chrześcijańskich] brak, jest ślepym

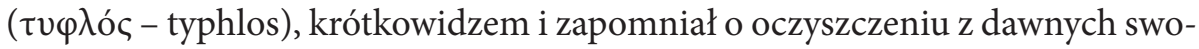
ich grzechów" (2 P 1,9).

Z lektury przytoczonych tekstów wynika zatem, ze Autorzy biblijni posługiwali się terminem $\tau v \varphi \lambda$ ó (typhlos), aby określić ślepego bądź w wymiarze fizycznym, bądź duchowym.

Ostatni zaproszeni na ucztę, rekrutowali się z grona ludzi chromych ( $\chi \omega \lambda$ où $\varsigma$ - cholous; Łk 14,21).

Występujący w analizowanej perykopie przymiotnik $\chi \omega \lambda$ ó (cholos), określa człowieka bez nogi lub z niedowładem nóg. Oznacza zatem kulawego, kule-

14 Zob. X. Leon-Dufour, Stownik Nowego Testamentu, s. 637; L. Roy, Ubodzy, s. 998; J. Łach, Błogosławieni ubodzy w duchu (Mt 5,3), s. 43.

15 Zob. R. Popowski, Wielki słownik grecko-polski Nowego Testamentu, s. 540.

16 Zob. K. Zisler, Ułomności, kol. 1359; R. Popowski, Wielki słownik grecko-polski Nowego Testamentu, s. 38.

17 Zob. X. Leon-Dufour, Słownik Nowego Testamentu, s. 602; R. Popowski, Wielki słownik grecko-polski Nowego Testamentu, s. 613; H. Gollinger, Ślepy, kol. 1279. 
jącego, utykającego i chromego, a w Nowym Testamencie pojawia się $14 \mathrm{razy}^{18}$, np.: „Idźcie i oznajmijcie Janowi to, co słyszycie i na co patrzycie: niewidomi wzrok odzyskują, chromi ( $\chi \omega \lambda$ oì - choloi) chodzą [...]” (Mt 11,4-5). „Wśród nich leżało mnóstwo chorych: niewidomych, chromych ( $\chi \omega \lambda \tilde{\omega} v-$ cholon) i sparaliżowanych” (J 5,3). „W Listrze mieszkał pewien człowiek, [...] kaleka ( $\chi \omega \lambda$ ò $\varsigma$ - cholos) od urodzenia" (Dz 14,8).

Goście zatem zaproszeni na ucztę wywodzili się z marginesu społecznego. Rekrutowali się z grona ludzi ubogich, chorych i cierpiących, a takich właśnie w czasach biblijnych spychano poza nawias społeczeństwa i traktowano jak osoby niepożądane.

W Starym i Nowym Testamencie błędnie bowiem wierzono, że ubóstwo, choroba i cierpienie są karą Bożą. Są karą za grzechy i przewinienia własne bądź przodków (zob. np. J 9,2) ${ }^{19}$. W efekcie na ludzi cierpiących spoglądano jak na jawnych grzeszników, ze wszystkimi tego konsekwencjami. Na przykład trędowatych w bezlitosny sposób wręcz wyeliminowano ze wspólnoty społeczno-religijnej. Zobowiązano ich bowiem, by trzymali się z daleka od zdrowych. Nakazano im także, by każdorazowo, z bezpiecznej odległości, sygnalizowali swoją obecność i ostrzegali zdrowych przed niepożądanym spotkaniem (Kpł 13,45-46). Z kolei przedstawicieli rodu kapłańskiego - jeśli posiadali jakiekolwiek oznaki ułomności czy chronicznej choroby - bezwzględnie wykluczano z posługi kapłańskiej (Kpł 21,17-23). Warto wspomnieć, że nawet okaleczone zwierzęta uważano za gorszej jakości i stanowczo zabraniano składania ich Bogu w ofierze (Kpł 1,3.10; Ml 1,8).

Gospodarz uczty okazał się więc człowiekiem nad wyraz odważnym. Przyjął bowiem do swego domu osoby, których nikt inny by nie ugościł.

Mimo tego przy jego gościnnym stole zostało jeszcze wiele wolnych miejsc (Łk 14,22). Zobowiązał więc swojego sługę, by ten wyszedł na drogi i między opłotki, i tym razem już nie prosił, a zmuszał do przyjścia na ucztę (Łk 14,23). Sam zaś rozgniewany jeszcze postawą pierwszych gości postanowil, że żaden z nich już nigdy nie skosztuje uczty w jego domu (Łk 14,24).

18 Zob. K. Pauritsch, Chromy, kol. 167; R. Popowski, Wielki słownik grecko-polski Nowego Testamentu, s. 661-662.

19 Zob. J. Ćwikła, Syntetyczne spojrzenie na bogactwo w Starym Testamencie, s. 188-189 . 


\section{Przesłanie teologiczne zapisu kanonicznego $t k$ 14,15-24}

Głównym tematem przepowiadania Jezusa było orędzie zbawcze o królestwie Bożym. Jezus wielokrotnie głosił bowiem: „Czas się wypełnił i bliskie jest królestwo Boże. Nawracajcie się i wierzcie w Ewangelię” (Mk 1,15). „[...] Jeśli Ja palcem Bożym wyrzucam złe duchy, to istotnie przyszło już do was królestwo Boże” (Łk 11,20). Wielokrotnie głosił również: „Starajcie się najpierw o królestwo Boga i o Jego sprawiedliwość, a [...] wszystko będzie wam dane” (Mt 6,33). „Przyjdźcie do Mnie wszyscy, którzy utrudzeni i obciążeni jesteście, a Ja was pokrzepię" (Mt 11,28).

Z lektury Jego wypowiedzi wynika, że na ucztę w królestwie niebiańskim zostali zaproszeni wszyscy ludzie. Zostali zaproszeni zarówno Żydzi, jak i poganie (Mt 22,1-14); zarówno bogaci, jak i ubodzy (Łk 14,15-24). Jednak przed wszystkimi postawiono równie trudne wymagania. Do królestwa Bożego prowadzi bowiem waska droga i ciasna brama (Mt 7,13). A Jezus żądał i żąda od swoich uczniów całkowitego posłuszeństwa i radykalnych wyrzeczeń ${ }^{20}$ : „Jeśli kto chce pójść za Mną, niech się zaprze samego siebie, niech weźmie krzyż swój i niech Mnie naśladuje” (Mk 8,34). „Kto miłuje ojca lub matkę bardziej niż Mnie, nie jest Mnie godzien” (Mt 10,37). „Idź, sprzedaj wszystko, co masz i chodź za Mną” (Mk 10,21). „Nie każdy, kto Mi mówi Panie, Panie, wejdzie do królestwa niebieskiego, lecz ten, kto spełnia wolę mojego Ojca, który jest w niebie" (Mt 7,21).

Żądania te są nad wyraz trudne. Naśladowca Jezusa musi bowiem w zdecydowany sposób odrzucić wszystko, co do tej pory było dla niego ważne i cenne. Zobowiązany jest do zerwania więzi rodzinnych (Mt 19,29; Mk 10,29; Łk 18,29) i do porzucenia dóbr materialnych $(Ł k \text { 18,28 })^{21}$. Musi zatem, w zde-

20 Zob. R. Schnackenburg, Nauka moralna Nowego Testamentu, s. 46; J. Gnilka, Jezus $z$ Nazaretu. Orędzie i dzieje, s. 196; H. Langkammer, Biblijne podstawy duchowości chrześcijańskiej, s. 63-64; P. Góralczyk, Etyka Królestwa Bożego, s. 50; J. Kudasiewicz, Centralne tematy teologiczno-etyczne Kazania na Górze (Mt 5-7), s. 85-86; M. Machinek, Kazanie na Górze. Profetyczna prowokacja czy program życiowy, s. 97; R. L. Recalde, Błogosławieństwa Ewangelia i program życia, s. 20; J. Kudasiewicz, Królestwo Boże w nauczaniu Jezusa, s. 163; R. Meynet, Czytaliście św. Łukasza? Przewodnik, który prowadzi do spotkania, s. 170-171; D. Stern, Komentarz żydowski do Nowego Testamentu, s. 224-225; A. Sicari, Objawienie rad ewangelicznych, s. 24-25; J. Kudasiewicz, Teologia Ewangelii synoptycznych, s. 114-115; W. Harrington, Klucz do Biblii, s. 406; M. Bednarz, Ewangelie synoptyczne, s. 271; J. Kudasiewicz, Ewangelie synoptyczne dzisiaj, s. 266-267.

21 Zob. R. Schnackenburg, Nauka moralna Nowego Testamentu, s. 43; R. Meynet, Czytaliście św. Łukasza? Przewodnik, który prowadzi do spotkania, s. 170-171. 
cydowany sposób, z grona wielu wartości wybierać nie Mamonę, a Boga (Mt 6,24; Łk 16,13), nie wartości doczesne, a wieczne i oczywiście nie zło, a dobro.

Jednak nie wszyscy są do tego zdolni. W gronie zaś tych, którzy nie sprostali wymaganiom królestwa niebiańskiego, znaleźli się również bogaci bohaterowie perykopy o uczcie (Łk 14,15-24). Oni bowiem byli do tego stopnia uwikłani w sprawy doczesne, że bez wahania zamiast zaproszenia na ucztę, wybrali swoją pracę i dobra materialne (Łk 14,18-19) oraz życie rodzinne (Łk 14,20) $)^{22}$.

W Starym Testamencie praca uchodziła za wartość pozytywną. Autorzy biblijni uczyli bowiem, że to sam Bóg u progu dziejów ludzkości zobowiązał człowieka do pracy. A w słowach: „Czyńcie sobie ziemię poddaną” (Rdz 1,28), zaprosił go nawet do współpracy w dziele stwarzania.

Człowiekowi jednak nigdy nie wolno działać według własnych projektów i zamiarów. Musi więc on zawsze respektować wolę Bożą i Jego zamysł stwórczy, a swoją pracę traktować jak powołanie. Bo jeśli nie, prędzej czy później, zbuntuje się przeciwko Bogu i zamiast przez pracę Mu służyć, będzie z Nim rywalizował, zamiast przez pracę uświęcać się, będzie pogrążał się w chaosie moralnym. W efekcie przyjdzie dzień, gdy definitywnie odrzuci Boga i Jego miłość, a z własnej pracy uczyni bożka oraz instrument wyzysku i wzbogacenia ${ }^{23}$.

W Nowym Testamencie pozytywnie o pracy wypowiadali się zarówno Jezus, jak i Jego uczniowie, szczególnie Paweł.

Jezus własnym przykładem nawet uświęcił wszelki ludzki trud i wysiłek. Urodził się bowiem w rodzinie Józefa, cieśli (Mt 13,55; Mk 6,3) i wraz z nim przez długie lata pracował fizycznie w warsztacie ciesielskim. Poznał zatem trud pracy robotnika. Paweł natomiast wzorem innych uczonych w Piśmie i faryzeuszów, wyuczył się jednego z zawodów rzemieślniczych i został wytwórcą namiotów (Dz 18,3). I właśnie w ten sposób zarabiał na życie, i z dumą się z tym obnosit.

Jezus podczas swojej publicznej działalności, wielokrotnie pochylał się nad ubogimi, którzy żyli z pracy swoich rąk. Pochylał się nad nimi i doceniał ich trud. Szanował więc ich wysiłek zdobywania środków do życia ${ }^{24}$. Gdy chodzi

22 Zob. G. Schiwy, Weg ins Neue Testament. Kommentar und material, s. 349; J. Ernst, Das Evangelium nach Lukas, s. 301; M. Wojciechowski, Przypowieści dla nas, s. 99.

23 Zob. J. Kudasiewicz, Nowotestamentalne rozumienie pracy na tle ówczesnych pogladów, s. 51-52; Cz. Bartnik, Ręka i myśl. Teologia pracy, odpoczynku i świętowania, s. 322; A. Koprowski, Chrześcijańska wartość pracy, s. 1397-1412; M. Filipiak, Sens ludzkiego życia $w$ świetle Biblii, s. 193; A. Grabner-Haider, Praca, kol. 1030; J. Szlaga, Jezus o pracy i dobrach materialnych, s. 1634-1643; J. Ćwikła, Przyczyny starotestamentalnego osądu bogaczy, s. $53-56$.

24 Zob. J. Kudasiewicz, Nowotestamentalne rozumienie pracy na tle ówczesnych pogladów, s. 52. 
o Pawła, to pracował fizycznie, nawet podczas swoich podróży misyjnych. Zarzucano mu bowiem, że jest Apostołem gorszej kategorii niż Dwunastu, zarzucano mu, że właściwie nie ma prawa do godności apostolskiej (1 Kor 9,2). Stąd by nie być dla nikogo ciężarem i jeść własny chleb (1 Tes 2,9; 2 Tes 3,8), w miarę możności pracował jako wytwórca namiotów (Dz 18,3).

Jezus swoim nauczaniem nigdy nie dawał powodu, by sądzić, że negował wartość pracy i że domagał się odrzucenia jej a priori. Co prawda nauczał: „Przypatrzcie się ptakom w powietrzu: nie sieją, ani żną i nie zbierają do spichlerzy, a Ojciec wasz niebieski je żywi. Czy wy nie jesteście ważniejsi niż one?” (Mt 6,26); nauczał również: „Przypatrzcie się liliom na polu, jak rosną: nie pracują ani przędą. A powiadam wam: nawet Salomon w całym swoim przepychu nie był tak ubrany jak jedna z nich" (Mt 6,28-29), to jednak już w IV wieku Jan Chryzostom ${ }^{25}$ zauważył, że słowa te nie były zachętą do porzucenia pracy, ale wezwaniem do właściwego stosunku do pracy. Były przede wszystkim zachętą do zawierzenia się Bogu i zaufania Jemu. Ostatecznie przecież Jezus nie namawiał swoich uczniów, aby nie siali (zob. Mt 6,26) i nie pracowali (zob. Mt 6,28), lecz by zbytnio nie troszczyli się o sprawy doczesne. Paweł swoim nauczaniem, również nigdy nie negował wartości pracy. Warto wspomnieć, że gdy któregoś dnia dowiedział się, iż Tesaloniczanie opacznie zrozumieli jego naukę na temat Paruzji i czekając na koniec świata zaczęli porzucać pracę, przyjął to z bólem. Namawiał więc ich do powrotu do pracy, a opornych karcił: „Kto nie chce pracować, niech też nie je" (2 Tes 3,10).

Jezus zatem ani swoim przykładem, ani nauczaniem nigdy nie zachęcał swoich naśladowców, aby z założenia unikali pracy i lekkomyślnie pozbawiali się środków do życia. Zachęcał ich natomiast, aby byli ludźmi dojrzałymi, duchowo ukształtowanymi i wewnętrznie wolnymi ${ }^{26}$. Namawiał, by w swej wolności, prawidłowo dokonywali wyborów, by zawsze pełnili wolę Bożą i wreszcie, by dla Boga potrafili zrezygnować ze wszystkiego, w tym z pracy i dóbr materialnych, jeżeli tego od nich zażąda. Chciał więc, aby Jego uczniowie byli tak wolni, jak chociażby bohaterowie paraboli o skarbie i perle (Mt 13,44-46).

Oni bowiem całą swoją ufność pokładali w Bogu. Jego zaś wola była dla nich najważniejsza. Gdy więc któregoś dnia znaleźli drogocenny skarb króle-

25 Jan Chryzostom żył w latach 344-407. Pochodził z zamożnej rodziny, z Antiochii. Przyjął chrzest jako dorosły człowiek (372 r.). Będąc gorliwym neofitą, poświęcił się życiu religijnemu, a nawet mistycznemu. Wiele czasu spędzał więc na modlitwie i pogłębianiu wiedzy teologicznej. W 381 r. został diakonem, w 386 r. - kapłanem, a w 398 r. - biskupem. Zasłynął jako wybitny kaznodzieja. Jego zaś dorobek literacki przewyższa spuściznę pisarską wszystkich Ojców Wschodu. Na Zachodzie dorównywał mu jedynie Augustyn. (Zob. B. Altaner, A. Stuiber, Patrologia. Życie, pisma i nauki Ojców Kościoła, s. 434-435).

26 Zob. M. Riber, Praca w Biblii, s. 140. 
stwa niebiańskiego (Mt 13,44-46), sprzedali wszystko, co do tej pory posiadali i nabyli go.

Zatem dwaj pierwsi zaproszeni na ucztę (Łk 14,15-24) definitywnie zostali z niej wykluczeni, nie dlatego, że zaangażowali się w pracę i posiadali dobra materialne, ale dlatego, że mieli niewłaściwy stosunek do pracy i dóbr materialnych. Zostali wykluczeni, gdyż w ich hierarchii wartości Bóg zajmował nie pierwsze, a dalsze miejsce. Zostali wykluczeni, ponieważ nie królestwo Boga i Jego sprawiedliwość były dla nich najważniejsze, a sprawy doczesne.

Uczniom Jezusa nie wolno naśladować niechlubnych bohaterów analizowanego fragmentu Łk 14,15-24. Oczywiście chrześcijanie mogą pracować. Wręcz muszą i to w miejscu zgodnym z wolą Bożą. Jednak nigdy nie wolno im z pracy i dóbr materialnych uczynić bożka. Nie wolno im zatem pod żadnym pozorem spychać Boga poza nawias swojego życia. Mało tego, muszą całkowicie zawierzyć się Bogu i żyć tylko dla Niego. Bo jeśli nie, z pewnością podzielą los niechlubnych bohaterów omawianej perykopy i także zostaną wykluczeni $\mathrm{z}$ udziału w uczcie niebiańskiej.

Z kolei trzeci z zaproszonych na ucztę odrzucił zaproszenie, ponieważ właśnie poślubił żonę (Łk 14,20).

W czasach Starego Testamentu małżeństwo uchodziło za wartość pozytywną. Uważano je wtedy niemalże za obowiązek Izraelity $(\operatorname{Rdz} 1,28)^{27}$. Dlatego też tylko ludzi żonatych i posiadających rodzinę, traktowano jako pełnowartościowych obywateli narodu wybranego. Samotnych zaś pozbawionych potomstwa lekceważono, wręcz pogardzano nimi ${ }^{28}$.

W Nowym Testamencie zarówno Jezus, jak i Jego uczniowie, głównie Paweł, także pozytywnie wypowiadali się na temat małżeństwa.

Jezus swoją obecnością na godach w Kanie Galilejskiej uświęcił nawet związek małżeński obecnych tam nowożeńców (J 2,1-11). Swoimi zaś radykalnymi wypowiedziami na temat małżeństwa, zasłynął jako zdecydowany przeciwnik rozwodów. Uczył bowiem: „Co Bóg złączył, tego niech człowiek nie rozdziela” (Mk 10,9). „Kto oddala swoją żonę, a bierze inną, popełnia cudzołóstwo względem niej. I jeśli żona opuści swego męża, a wyjdzie za innego, popełnia cudzołóstwo" (Mk 10,11-12).

27 Zob. E. Zawiszewski, Instytucje biblijne, s. 29-30; R. Pesch, Małżeństwo, kol. 695; X. Leon-Dufour, Słownik Nowego Testamentu, s. 380; J. Gnilka, Jezus z Nazaretu. Orędzie idzieje, s. 215.

28 W Izraelu, czasów biblijnych, ludzi bezżennych traktowano na równi z tymi, którzy przelali krew. Nie akceptowano bowiem wtedy celibatu, a samotnych dyskryminowano. Na przykład celibariusz nie mógł założyć szkoły i zostać rabinem. Należy jednak dodać, że mnisi w Qumran nie przestrzegli tych zasad i od kandydatów do swojej wspólnoty wymagali właśnie bezżenności. (Zob. J. Gnilka, Jezus z Nazaretu. Orędzie i dzieje, s. 215). 
Jezus pozytywnie wypowiadał się na temat małżeństwa, ale sam żył w bezżenności. Rodzi się pytanie: dlaczego? Otóż w ten sposób - w izraelskim, patriarchalnym środowisku, wielce nieprzychylnym dla bezżenności - chciał zaświadczyć, że w życiu doczesnym należy kierować się nie tradycją i zwyczajami, a wolą Bożą. Jeżeli zatem Bóg zażąda, to dla Boga i Jego królestwa, nawet wbrew ludzkim opiniom, należy zrezygnować ze wszystkiego, nie tylko z dóbr materialnych, ale i z małżeństwa, prokreacji oraz potomstwa. I tak postąpił.

Także Paweł, naśladując Mistrza z Nazaretu, przeszedł przez życie jako celibatariusz. Stanowczo jednak trzeba podkreślić, że od chrześcijan nie wymagał bezżenności. Wskazywał co prawda na prymat celibatu nad małżeństwem (1 Kor 7,32), jednak nie pogardzał tym ostatnim. Uczył co prawda, że samotność i celibat są korzystniejsze dla sprawy królestwa Bożego, ale nie niezbędne (1 Kor 7,26). Stąd nie zabraniał małżeństw (1 Kor 7,28). A gdy dowiadywał się, ze komuś grożą grzechy nieczyste, jako lek zalecał właśnie życie małżeńskie (1 Kor 7,9). Gdy chodzi o rozwody, był ich przeciwnikiem $(1$ Kor 7,10).

Zatem trzeci z zaproszonych na ucztę (Łk 14,15-24) definitywnie został z niej wykluczony, nie dlatego, że ożenił się, ale dlatego, że źle pojmował miłość do żony (Łk 14,20). Uczynił bowiem z niej alternatywę dla miłości do Boga. W efekcie przestał kochać Stwórcę, a żonę zaczął miłować w bałwochwalczy sposób. Jego więc miłość do żony w rażący sposób kontrastowała z miłością, jaką Abraham żywił do swojej rodziny, najpierw do ukochanej Sary, potem do Izaaka.

W XVIII wieku przed Chrystusem Bóg wystawił Abrahama na próbę ${ }^{29}$. Zażądał od niego ofiary z Izaaka. Patriarcha bez wahania postanowił spełnić to żądanie. Postanowił je spełnić, ponieważ bardziej kochał Stwórcę niż syna.

Jednak w jego przypadku słowo bardziej nie oznacza siły uczuć, ale ich kolejność. Abraham bowiem najpierw kochał Boga, źródło wszelkiej miłości, potem dopiero syna. Jego więc miłość do Boga była pierwsza i nadrzędna w stosunku do miłości do syna. Stąd Boga kochał jak Pana i Dawcę wszelkich darów, Izaaka natomiast - jak dar Boży. W efekcie jego miłość do syna wpisywała się przez podporządkowanie w miłość do Boga i była jej owocem. Oczywiście, obie te miłości nie konkurowały ze sobą, ale wzajemnie się uzupełniały. Stanowiły wręcz jedność. W konsekwencji Abraham jedną, krystalicznie czystą miłością kochał zarówno Boga, jak i syna. Gdy więc kochał Boga, kochał i syna. Kiedy zaś miłował syna, równocześnie miłował Boga. A sytuacja graniczna, w jakiej

29 Zob. W. Zimmerli, 1 Mose 12-25. Abraham. Zürcher Bibelkommentare, s. 108-115; C. Schedl, Historia Starego Testamentu. Lud Bożego Przymierza, t. II, s. 52-54; H. Daniel-Rops, Od Abrahama do Chrystusa, s. 22-23; M. Peter, Ksiega Rodzaju, s. 41; G. Ravasi, Ksiega Rodzaju (12-50), s. 130-131. 
się znalazł, a mianowicie próba, jakiej został poddany, pokazała, że dla Boga, gotów był poświęcić wszystko, nawet ukochanego syna. Udowodniła zatem, że Bóg, źródło wszelkiej miłości, był dla niego najważniejszy.

Z lektury omawianej perykopy Łk 14,15-24 wynika, że trzeci z zaproszonych na ucztę, nie był zdolny do takiej miłości. Dlatego też jego bałwochwalcza miłość do żony, ostatecznie stała się powodem jego potępienia.

Oczywiście z analizowanego zapisu nie wynika, jakoby uczniom Jezusa nie wolno było wstępować w związki małżeńskie. Wręcz przeciwnie, mogą oni wstępować w związki małżeńskie, ale pod warunkiem, że taka będzie wola Boża względem nich. Jednak nawet wówczas nie wolno im z miłości małżeńskiej, czynić miłości alternatywnej w stosunku do miłości, do Boga. Bo jeśli to uczynią, z pewnością podzielą los trzeciego z zaproszonych na ucztę. I jak on definitywnie zostaną wykluczeni z udziału w uczcie niebiańskiej.

Konkludując należy stwierdzić, że trzej niechlubni bohaterowie omawianej perykopy, zostali wykluczeni z udziału w uczcie niebiańskiej, gdyż uwikłali się w sprawy doczesne. Uwikłali się do tego stopnia, że stali się chronicznie obojętni na sprawy Boże. Stali się trwale niezdolni do nawrócenia.

Skoro bogacze odrzucili zaproszenie na ucztę, zaproszono na nią ubogich, a ci z radością przyszli. I okazało się - wbrew starotestamentalnym opiniom że są oni ludźmi pokornymi i wewnętrznie wolnymi, ubogimi $w$ duchu (Mt 5,3) i czystego serca (Mt 5,8). Okazało się, że są ludźmi głębokiej wiary i zawierzenia. $\mathrm{Z}$ tego więc względu, że ich sercami nie miotały ani żądze i namiętności, ani ułuda bogactwa, zasłużyli na udział w życiu wiecznym. Zasłużyli na udział w uczcie niebiańskiej ${ }^{30}$.

Spełniły się zatem słowa Magnificat: „[Bóg] przejawia moc swego ramienia, rozprasza ludzi pyszniących się zamysłami serc swoich. Strąca władców z tro$\mathrm{nu}$, a wywyższa pokornych. Głodnych nasyca dobrami, a bogatych z niczym odprawia” (Łk 1,51-53).

\section{Podsumowanie}

W niniejszym artykule przeanalizowano perykopę o uczcie (Łk 14,15-24). Przeanalizowano ją pod względem literackim, semantycznym i teologicznym.

Wykazano, że przypowieść o uczcie pierwotnie należała do źródła Q, że z tego źródła zaczerpnęli ja zarówno Łukasz, Mateusz, jak i Tomasz, autor apo-

30 Zob. L.J. Hoppe, Being poor. A Biblical study, s. 153-154; J. Łach, Błogosławieni ubodzy w duchu (Mt 5,3), s. 44; H.U. Baltazar, Ubóstwo Chrystusa, s. 14; P. Góralczyk, Ubóstwo duchowe, a ubóstwo materialne, s. 48. 
kryfu. Dowiedziono przy tym, że wersja Łukasza jest najkrótsza i najbliższa oryginałowi.

W toku analiz udowodniono także, że zapis o uczcie (Łk 14,15-24) jest ostrym upomnieniem skierowanym do wszystkich tych, którzy z grona wielu wartości wybierają nie Boga, a Mamonę, nie wartości duchowe, a materialne. Dowiedziono, że jest on ostrzeżeniem, iż konsekwencją grzesznych wyborów dokonywanych w doczesności, będzie wykluczenie z uczty niebiańskiej. Będzie potępienie wieczne.

Udowodniono zatem, że fragment o uczcie zachodzący w Ewangelii Łukasza (Łk 14,15-24), jest ostrą parenezą skierowaną przede wszystkim do bogaczy.

\section{Bibliografia}

Abramowiczówna Z., Stownik grecko-polski, t. I, PWN, Warszawa 1958.

Abramowiczówna Z., Słownik grecko-polski, t. III, PWN, Warszawa 1962.

Altaner B., Stuiber A., Patrologia. Życie, pisma i nauki Ojców Kościoła, (tłum. P. Pachciarek), PAX, Warszawa 1990.

Baltazar H. U., Ubóstwo Chrystusa, (tłum. F. Mickiewicz), Com 6, 5 (1986), s. 14-16.

Bartnik Cz., Ręka i myśl. Teologia pracy, odpoczynku i świętowania, Księgarnia św. Jacka, Katowice 1982.

Bednarz M., Ewangelie synoptyczne, Biblos, Tarnów 1994.

Ćwikła J., Przyczyny starotestamentalnego osądu bogaczy, Studia Bydgoskie 9 (2015), s. 41-57.

Ćwikła J., Syntetyczne spojrzenie na bogactwo w Starym Testamencie, Studia Bydgoskie 8 (2014), s. 185-203.

Daniel-Rops H., Od Abrahama do Chrystusa, (tłum. Z. Starowieyska-Morstinowa), PAX, Warszawa 2011.

Dodd Ch. H., Przypowieści o Królestwie, (tłum. J. Marzęcki), PAX, Warszawa 1981.

Ernst J., Das Evangelium nach Lukas, St. Benno-Verlag GmbH, Leipzig 1977.

Ewangelie Apokryficzne, w: Apokryfy Nowego Testamentu, red. M. Starowieyski, t. I, TN KUL, Lublin 1986.

Filipiak M., Sens ludzkiego życia w świetle Biblii, w: Studio lectionem facere, red. S. Łach, J. Szlaga, KUL, Lublin 1980, s. 193-197.

Gnilka J., Jezus z Nazaretu. Orędzie i dzieje, (tłum. J. Zychowicz), Znak, Kraków 1997.

Gollinger H., Ślepy, w: Praktyczny Słownik Biblijny, red. A. Grabner-Haider, (tłum. T. Mieszkowski, P. Pachciarek), PAX, Warszawa 1994, kol. 1279-1280.

Góralczyk P., Etyka Królestwa Bożego, Com 6, 2 (1986), s. 43-56.

Góralczyk P., Ubóstwo duchowe, a ubóstwo materialne, Com 6, 5 (1986), s. 48-57.

Grabner-Haider A., Praca, w: Praktyczny Słownik Biblijny, red. A. Grabner-Haider, (tłum. T. Mieszkowski, P. Pachciarek), PAX, Warszawa 1994, kol. 1030-1032. 
Grundmann W., Das Evangelium nach Lukas. Theologischer Handkommentar zum Neuen Testament, Evangelische Verlagsanstalt, Berlin $1964^{3}$.

Gryglewicz F., Ewangelia według św. Łukasza. Wstęp - przekład z oryginału - komentarz, t. III/3, Pallottinum, Poznań-Warszawa 1974.

Harrington W., Klucz do Biblii, (tłum. J. Marzęcki), PAX, Warszawa 2012.

Hoppe L. J., Being poor. A Biblical study, (Good News Studies), Wilmington 1987.

Jankowski A., Królestwo Boże w przypowieściach, Wydawnictwo Benedyktynów, Kraków-Tyniec 1997.

Koprowski A., Chrześcijańska wartość pracy, Znak 19, 11 (1967), s. 1397-1412.

Kudasiewicz J, Królestwo Boże w nauczaniu Jezusa, RTK 30, 6 (1983), s. 153-166.

Kudasiewicz J., Centralne tematy teologiczno-etyczne Kazania na Górze (Mt 5-7), AK 63, 1 (1971), s. 80-91.

Kudasiewicz J., Ewangelie synoptyczne dzisiaj, Apostolicum, Ząbki 1999.

Kudasiewicz J., Nowotestamentalne rozumienie pracy na tle ówczesnych pogląów, w: Społeczny wymiar orędzia biblijnego, red. T. Makowski, Gaudentinum, Gniezno-Bydgoszcz 1994, s. 49-61.

Kudasiewicz J., Teologia Ewangelii synoptycznych, w: Teologia Nowego Testamentu, red. F. Gryglewicz, t. I, RW KUL, Lublin, 1986.

Łach J., Błogosławieni ubodzy w duchu (Mt 5,3), Com 6, 5 (1986), s. 40-47.

Langkammer H., Biblijne podstawy duchowości chrześcijańskiej, Wydawnictwo Wrocławskiej Księgarni Archidiecezjalnej, Wrocław 1987.

Leon-Dufour X., Słownik Nowego Testamentu, (tłum. K. Romaniuk), Księgarnia św. Wojciecha, Poznań 1993.

Loska T., Ewangelie z komentarzem duszpasterskim, WAM, Kraków 2011.

Machinek M., Kazanie na Górze. Profetyczna prowokacja czy program życiowy, RBL 51, 2 (1998), s. 87-101.

Mattern L., Przypowieść o uczcie, w: Praktyczny Słownik Biblijny, red. A. Grabner-Haider, (tłum. T. Mieszkowski, P. Pachciarek), PAX, Warszawa 1994, kol. 1095.

Meynet R., Czytaliście św. Łukasza? Przewodnik, który prowadzi do spotkania, (tłum. K. Łukowicz), WAM, Kraków 1998.

Ohler A., Hierzenberger G., Sługa, w: Praktyczny Słownik Biblijny, red. A. Grabner-Haider, (tłum. T. Mieszkowski, P. Pachciarek), PAX, Warszawa 1994, kol. 1211.

Pauritsch K., Chromy, w: Praktyczny Słownik Biblijny, red. A. Grabner-Haider, (tłum. T. Mieszkowski, Paweł Pachciarek), PAX, Warszawa 1994, kol. 167.

Pesch R., Małżeństwo, w: Praktyczny Słownik Biblijny, red. A. Grabner-Haider, (tłum. T. Mieszkowski, P. Pachciarek), PAX, Warszawa 1994,. kol. 695-698.

Peter M., Księga Rodzaju, w: PŚSiNT, t. I, red. M. Peter (ST), M. Wolniewicz (NT), Księgarnia św. Wojciecha, Poznań 1998, s. 4-90.

Popowski R., Wielki słownik grecko-polski Nowego Testamentu, wydanie z pełna lokalizacja greckich haset, kluczem polsko-greckim oraz indeksem form czasownikowych, Vocatio, Warszawa 1995.

Pytel J. K., List do Filipian, w: PŚSiNT, t. IV, red. M. Peter (ST), M. Wolniewicz (NT), Księgarnia św. Wojciecha, Poznań 1998, s. 469-476. 
Ravasi G., Księga Rodzaju (12-50), (tłum. M. Brzezinka), Wydawnictwo m, Kraków 1998.

Recalde R. L., Błogosławieństwa - Ewangelia i program życia, (tłum. B. Szatyński), Com 6, 5 (1986), s. 17-30.

Riber M., Praca $w$ Biblii, PAX, Warszawa 1979.

Ricciotti G., Życie Jezusa, (tłum. J. Skowroński), PAX-ADAM, Warszawa 2000.

Romaniuk K., Jankowski A., Stachowiak L., Komentarz praktyczny do Nowego Testamentu, t. I, Pallottinum, Poznań-Kraków 1999.

Romaniuk K., Morfokrytyka i historia redakcji czyli Form- i Redaktionsgeschichte, ATK, Warszawa 1983.

Romaniuk K., Przyjacielu, jakżeś tu wszedł nie mając szaty godowej (Mt 22, 1-14), RBL 22, 4-5 (1969), s. 267-276.

Roy L., Ubodzy, w: Słownik Teologii Biblijnej, red. X. Leon - Dufour, (tłum. K. Romaniuk), Pallottinum, Poznań, 1990, s. 998-1002.

Rubinkiewicz R., Przypowieść o szacie godowej (Mt 22,11-13) w świetle Hen 10,4, RTK 27, 1 (1980), s. 53-69.

Schedl C., Historia Starego Testamentu. Lud Bożego Przymierza, t. II, (tłum. S. Stańczyk), Mała Poligrafia Redemptorystów, Tuchów 1995.

Schiwy G., Weg ins Neue Testament. Kommentar und material. Das Evangelium nach Matthäus, Markus und Lukas, Bd. I, Echter-Verlag, Würzburg 1966.

Schnackenburg R., Nauka moralna Nowego Testamentu, (tłum. F. Dylewski), PAX, Warszawa 1983.

Sicari A., Objawienie rad ewangelicznych, (tłum. L. Balter), Com 5, 6 (1985), s. 9-28.

Stern D., Komentarz żydowski do Nowego Testamentu, Vocatio, Warszawa 2004.

Szlaga J., Jezus o pracy i dobrach materialnych, Znak 28 (1976), s. 1634-1643.

Szymanek E., Wykład Pisma Świętego Nowego Testamentu, Pallottinum, Poznań 1990.

Wojciechowski M., Przypowieści dla nas, Edycja św. Pawła, Częstochowa 2007.

Wolniewicz M., Ewangelia według Łukasza, w: PŚSiNT, t. IV, red. M. Peter (ST), M. Wolniewicz (NT), Księgarnia św. Wojciecha, Poznań 1998, s. 147-216.

Zawiszewski E., Instytucje biblijne, Bernardinum, Pelplin 2001.

Zimmerli W., 1 Mose 12-25. Abraham. Zürcher Bibelkommentare, Theologischer Verlag, Zürich 1976.

Zisler K., Ułomności, w: Praktyczny Słownik Biblijny, red. A. Grabner-Haider, (tłum. T. Mieszkowski, P. Pachciarek), PAX, Warszawa 1994, kol. 1359. 